\title{
International Law Post-Pandemic
}

Citation for published version (APA):

Menezes, W., \& Marcos, H. (2020). International Law Post-Pandemic. In G. L. Obregón Salinas (Ed.), Lo Multidisciplinario del Antes y Después del Covid-19 (pp. 85-114). Thomson Reuters.

https://doi.org/10.2139/SSRN.3680205

Document status and date:

Published: 01/01/2020

DOI:

10.2139/SSRN.3680205

Document Version:

Accepted author manuscript (Peer reviewed / editorial board version)

Document license:

CC BY-ND

\section{Please check the document version of this publication:}

- A submitted manuscript is the version of the article upon submission and before peer-review. There can be important differences between the submitted version and the official published version of record.

People interested in the research are advised to contact the author for the final version of the publication, or visit the DOI to the publisher's website.

- The final author version and the galley proof are versions of the publication after peer review.

- The final published version features the final layout of the paper including the volume, issue and page numbers.

Link to publication

\footnotetext{
General rights rights.

- You may freely distribute the URL identifying the publication in the public portal. please follow below link for the End User Agreement:

www.umlib.nl/taverne-license

Take down policy

If you believe that this document breaches copyright please contact us at:

repository@maastrichtuniversity.nl

providing details and we will investigate your claim.
}

Copyright and moral rights for the publications made accessible in the public portal are retained by the authors and/or other copyright owners and it is a condition of accessing publications that users recognise and abide by the legal requirements associated with these

- Users may download and print one copy of any publication from the public portal for the purpose of private study or research.

- You may not further distribute the material or use it for any profit-making activity or commercial gain

If the publication is distributed under the terms of Article $25 \mathrm{fa}$ of the Dutch Copyright Act, indicated by the "Taverne" license above, 


\title{
INTERNATIONAL LAW POST-PANDEMIC
}

\author{
Wagner Menezes ${ }^{1}$ \\ and \\ Henrique Marcos $^{2}$
}

\begin{abstract}
This paper reflects on International Law in the face of the COVID19 (coronavirus disease 2019) viral pandemic. First, the article examines the role of International Law in the face of the COVID-19 pandemic, focusing mainly on the regulatory framework available to the World Health Organization (WHO). Then, based on the examination of the stance of some States in the face of the pandemic and the action of the WHO, the text points out evidence that the current geopolitical conjuncture still holds national sovereignty as a maxim. Further, the document explains how maintaining the primacy of sovereignty is not an adequate strategy to deal with contemporary times' global challenges. Finally, the article highlights the relevance of assuming a systemic perspective in the practice of contemporary International Law, which, despite its flaws, should still be used as an instrument for peace and international cooperation.
\end{abstract}

KEYWORDS: COVID-19. Public International Law. World Health Organization.

Approved version (June 2020). Publication info:

MENEZES, Wagner; MARCOS, Henrique. International Law Post-Pandemic. In: Gonzalo Levi Obregón Salinas (Org.). Lo Multidisciplinario del Antes y Después del Covid-19. Ciudad de México: Thomson Reuters, 2020. (ISBN 978607-474-571-9) (Forthcoming). Available at SSRN: https://ssrn.com/abstract $=3680205$

\footnotetext{
${ }^{1}$ Associate Professor at the University of São Paulo Law School (USP). Fellow Professor at the University of California Berkeley - Law. Post-doctorate in International Law at the University of Pádova (Italy). President of the Brazilian Academy of International Law (ABDI).

${ }^{2}$ Researcher and Ph.D. Candidate in Foundations and Methods of Law at Maastricht University (UM). Ph.D. Candidate in International and Comparative Law at the University of São Paulo (USP). Master in Legal Sciences from the Federal University of Paraíba (UFPB). Researcher at the Center for Studies in International Courts of the University of São Paulo (NETI-USP). Member of the Brazilian Academy of International Law (ABDI).
} 
Available at SSRN: https://ssrn.com/abstract $=3680205$

\section{INTRODUCTION}

The COVID-19 ("coronavirus disease 2019") viral pandemic is proving to be one of the most significant challenges facing humanity in its recent history. Responsible for a drama on a global scale, the severe acute respiratory syndrome coronavirus 2 ("SARSCoV-2") has no concern for cultural, religious or political affiliations. National limits, as well as transnational bureaucratic borders, have no significance for the microorganism. The coronavirus has been able to cross all the borders that humans have creatively established from the Eurasian steppes to the Andean mountains. In its molecular simplicity and absolute lack of ideological concern, the virus has exposed how incompetent humanity is in dealing with global affairs.

The current model of international regulation has failed. The World Health Organization (WHO) has precariously waved its responsibility, lately dispensing the first formal notifications of the calamity. When the WHO finally began to organize its strategy, trying to implement an improvised world plan, it was already too late for thousands of victims. The virus had already spread around the world.

In their supposedly self-sufficient domains, some national leaders preferred to focus on messianic speeches, capitalizing on the situation for local political gain, focusing on maneuvers that would benefit them in the upcoming elections. When the pandemic took shape, denial turned to despair, which led to legal acts so terrible that some major nations were accused of international piracy for illegal seizure of medical supplies belonging to other States.

Approaching barbarism, the political reaction to the pandemic exposed the institutional regalia that one day seemed to be in place. Under this new paradigm, the last hope remains in the hands of an old and often neglected friend to humanity. Science, whose funding was exhausted by many political leaders who accused it of being dispensable or unnecessary, is now being called upon to perform miracles. It must save everyone so that we can return to our daily lives as if nothing had happened. While we wait for a vaccine or some kind of wonderful cure to emerge as a result of the tireless

MENEZES, Wagner; MARCOS, Henrique. International Law Post-Pandemic. In: Gonzalo Levi Obregón Salinas (Org.). Lo Multidisciplinario del Antes y Después del Covid-19. Ciudad de México: Thomson Reuters, 2020. (ISBN 978-607-474-571-9). Available at SSRN: https://ssrn.com/abstract=3680205 
efforts of thousands of scientists worldwide, it is possible to ask whether what we should in fact do is return to the status quo ante.

The pandemic and, more importantly, our reactions to it can be a valuable chance for humanity to mature into a new world order. Thus, in these following pages, we present some preliminary reflections on the deontological role of International Law and what it should become. Less than an effort of prescience about the future that awaits us, we argue on what ought to be done with one of the main tools of coordination and pacification of the world: Contemporary International Law. We need to establish a new concept for International Law with dimensional impacts in its interpretation. Such a concept should be orchestrated by respect for humanity, as a normative principle, and the inevitable conclusion that national sovereignty cannot be kept as an undisputed maxim above the challenges faced globally by the human species.

In these terms, we will first analyze the legal role of existing International Law in the face of the COVID-19 pandemic, focusing in particular on the regulatory framework available to the WHO ("1"). Then, based on the examination of the stance of some States towards the pandemic and the action of the WHO, we will point out evidence that the current geopolitical conjuncture still holds national sovereignty as a maxim ("2"). Next, we will explain how maintaining the primacy of sovereignty is not the most appropriate way to deal with the global challenges of contemporary times ("3"). Finally, we highlight the relevance of legal practitioners taking a systemic perspective in international legal practice. Despite the flaws of contemporary International Law, it should still be used as an instrument for peace and international cooperation ("4"). In these terms, this work contributes as an investigation of the need to transform our international order into an appropriately universal normative framework. Under the grave risks posed by the current pandemic, the suggestion of a concretely unified global order is no longer a naïve, idealistic project but a matter of survival for the human species.

MENEZES, Wagner; MARCOS, Henrique. International Law Post-Pandemic. In: Gonzalo Levi Obregón Salinas (Org.). Lo Multidisciplinario del Antes y Después del Covid-19. Ciudad de México: Thomson Reuters, 2020. (ISBN 978-607-474-571-9). Available at SSRN: https://ssrn.com/abstract=3680205 


\section{CONTEMPORARY INTERNATIONAL LAW IN THE FACE OF THE PANDEMIC}

The creation of the United Nations (UN) represents the split between classical and contemporary International Law. It is possible to glimpse in the organization the emanation of a series of structural transformations that the world underwent after the Second World War; thus establishing a global order based on legal presuppositions that triggered a modeling process of a new international system conducive to cultural, economic, ideological and normative exchanges between the global and local levels. ${ }^{3-4}$ Moving away from the State-centric model, contemporary international society is characterized by the broad interrelationship of the various international actors, which translates into the intensification of transnational interactions through international practices of a public and private nature, including economic practices, interactions between peoples, and power relations between the center and the periphery of the world stage. ${ }^{5}$ Compared to its predecessor, the contemporary international society is based on other foundations and principles (social, legal, economic, and axiological parameters) and, accordingly, it demands the establishment of new legal paradigms. Therefore, contemporary International Law is built on instruments that can be considered ideological and normative vectors for regulating society and a source for the production and design of international rules. ${ }^{6}$

Due to a pluralizing process within the structure of International Law, it ceases to be an eminently State-centered legal regime. International Law echoes beyond that referential figure of the State. It can impact people's lives through measures that aim to

\footnotetext{
${ }^{3}$ MENEZES, Wagner. A ONU e o Direito Internacional Contemporâneo, in: CACHAPUZ DE MEDEIROS, Antônio Paulo (Org.). Desafios do Direito Internacional Contemporâneo (Jornadas de Direito Internacional Público no Itamaraty, 7 a 9 de novembro de 2005). Brasília: FUNAG, 2007. p. 326.

${ }^{4}$ BENVENISTI, Eyal. The Conception of International Law as a Legal System. German Yearbook of International Law, v. 50, p. 393-405, 2008.

${ }^{5}$ MENEZES, A ONU e o Direito Internacional Contemporâneo, p. 327.

${ }^{6}$ Ibid., p. 328.

MENEZES, Wagner; MARCOS, Henrique. International Law Post-Pandemic. In: Gonzalo Levi Obregón Salinas (Org.). Lo Multidisciplinario del Antes y Después del Covid-19. Ciudad de México: Thomson Reuters, 2020. (ISBN 978-607-474-571-9). Available at SSRN: https://ssrn.com/abstract=3680205
} 
respect the plural reality of its subjects as an instrument for implementing their social rights.

In this context, the UN has invoked the responsibility of being a joint forum to discuss world problems. Among its purposes are international peace and security, the promotion of human rights, the development of friendly relations between nations, and international cooperation to solve international problems of economic, social, cultural, humanitarian nature, and any others that benefit from harmonized transnational treatment. ${ }^{7}$ Furthermore, according to Article 1.4 of the Charter of the United Nations, the UN assumes the role of a harmonizing center for the action of the States to achieve the objectives of the Organization. To fulfill its mission, the UN has the collaboration of a number of organs, such as the Security Council (UNSC), the General Assembly (UNGA), the Economic and Social Council (ECOSOC), in addition to specialized entities that may have their action restricted to a specific regional network or may assume a universal vocation. ${ }^{8}$ In this way, a new idea about the role of international organizations concerning international society comes into existence. Together with the other actors, international organizations assume the role of thinking, shaping, and directing the actions of the subjects of International Law. Therefore, States no longer manage their destinies in isolation, but rather in joint forums on the international stage, in environments that are also led by intergovernmental bodies in the most varied organizations with diverse objectives. Thus, at least normatively, there is a shift in the focus of participation from an airtight domestic practice to the international arena, where the international organizations play a central role together with the other actors..$^{9-10-11}$

\footnotetext{
${ }^{7}$ Ibid., p. 330.

${ }^{8}$ Charter of the United Nations, Article 55.

${ }^{9}$ MENEZES, A ONU e o Direito Internacional Contemporâneo, p. 331.

${ }^{10}$ KIngsburY, Benedict. What, How, and Who Should Public International Law Regulate? New Problems of Global Administrative Governance. (Lecture Series). Available at: $<$ https://legal.un.org/avl/ls/Kingsbury IL.html $>$. Accessed on 27 jul. 2020.

${ }^{11}$ SLAUGHTER, Anne-Marie. The Real New World Order. Foreign Affairs, v. 76, n. 5, p. 183-197, 1997.
}

MENEZES, Wagner; MARCOS, Henrique. International Law Post-Pandemic. In: Gonzalo Levi Obregón Salinas (Org.). Lo Multidisciplinario del Antes y Después del Covid-19. Ciudad de México: Thomson Reuters, 2020. (ISBN 978-607-474-571-9). Available at SSRN: https://ssrn.com/abstract=3680205 
Concerning the coronavirus health crisis, the WHO stands out for its specialized role as the leading organization with a universal vocation in global public health. The organization was established on April 7, 1948 (World Health Day) and has its headquarters in Geneva, Switzerland. One of its primary documents is the "Constitution of the World Health Organization." ${ }^{12}$ The WHO is composed of the World Health Assembly in which each member has the right to one vote, an Executive Council of thirty-four persons appointed by the Assembly, and the Secretariat, which is headed by the Director-General. ${ }^{13}$

Articles 20 and 21 of the WHO Constitution endow the organization with binding and peremptory powers beyond the usual powers of an international organization. Thus, it disrupts the traditional (and superficial) line of thought that portrays international organizations as mere deliberative forums, devoid of objective command. ${ }^{14}$ Under these provisions, the atypical regulations issued by the decision of two-thirds of the members of the Health Assembly legally compel the member States of the organization. However, members who reject these rules and inform the WHO of their reservation within the time limit laid down in each case shall be exempted from complying with them. ${ }^{15}$ Some scholars criticize the WHO for not making use of this power in its usual practice. Despite these criticisms, through the use of these powers, the WHO issued the "International Health Regulations" (IHR) ${ }^{16}$ in 2005. Being an international legal norm, the IHR is binding on the one hundred and ninety-six States — including all member States — that have subscribed to the terms of the WHO Constitution.

\footnotetext{
${ }^{12}$ Henceforth, the "WHO Constitution."

${ }^{13}$ WHO Constitution, Article 9.

${ }^{14}$ WHO Constitution, Articles 20 and 21

${ }^{15}$ WHO Constitution, Article 22.

${ }^{16}$ VON BOGDANDY, Armin; VILLARREAL, Pedro. Critical Features of International Authority in Pandemic Response: The WHO in the COVID-19 Crisis, Human Rights and the Changing World Order. Rochester, NY: Social Science Research Network, 2020a. p. 3 .
}

MENEZES, Wagner; MARCOS, Henrique. International Law Post-Pandemic. In: Gonzalo Levi Obregón Salinas (Org.). Lo Multidisciplinario del Antes y Después del Covid-19. Ciudad de México: Thomson Reuters, 2020. (ISBN 978-607-474-571-9). Available at SSRN: https://ssrn.com/abstract=3680205 
The Director-General of the WHO also has extensive powers as well as monocratic competences. Among these, s/he holds power to determine a "public health emergency of international concern" (PHEIC). The PHEIC is an extraordinary tool in contemporary International Law, as it assures that a single person (the Director-General) has the power to make a formal declaration with full effect. ${ }^{17}$ The PHEIC has no power to create new obligations for States (it cannot innovate). Its declaration can serve to activate regulatory instruments already in force, but which depends on the determination of a PHEIC to become active. ${ }^{18}$ So far, the Director-General of the WHO has declared a PHEIC on six occasions: The H1N1 flu pandemic in 2009, the wild poliovirus (polio) in 2014, the outbreak of Ebola ("ebola virus disease" or EVD) in Africa in 2014, the outbreak of the zika virus (ZIKV) in the Americas in 2016, the outbreak of Ebola in the Democratic Republic of Congo in 2019, and finally the COVID-19 pandemic in 2020. ${ }^{19}$ In addition to the coronavirus pandemic PHEIC declared in January 2020, polio and Ebola in Congo PHEIC are still active.

Alongside PHEIC, the WHO's power to issue "recommendations" that can be permanent or temporary and range from the most subtle (to examine routes carried out in the affected areas) to the most invasive (to deny the exit or entry of people, and to declare social isolation or quarantine) deserves mention. ${ }^{20-21}$ Open terminology allows

\footnotetext{
${ }^{17}$ IHR, Article 12.

${ }^{18}$ VON BOGDANDY; VILLARREAL, Critical Features of International Authority in Pandemic Response, p. 4.

${ }^{19}$ WHO, World Health Organization. IHR Emergency Committee on Novel Coronavirus (2019-nCoV), World Health Organization, Available at:
} $<$ https://www.who.int/dg/speeches/detail/who-director-general-s-statement-on-ihr-emergencycommittee-on-novel-coronavirus-(2019-ncov)>, accessed on: 9 jun. 2020.

${ }^{20}$ IHR, Article 18.

${ }^{21}$ According to Benedetto Conforti: "Specialized institutions, such as the United Nations, usually issue recommendations or predispose draft conventions and then exhaust their activity in a phase where there is little legal relevance. In some cases, however, they mostly emanate binding decisions for member states, or rather (as in the case of WHO, ICAO, etc.) decisions that become binding if states do not manifest, within a certain period of time, the will to repudiate them. Such decisions will in fact fall within the scope of the agreement, i.e. the institutional agreement of the relative

MENEZES, Wagner; MARCOS, Henrique. International Law Post-Pandemic. In: Gonzalo Levi Obregón Salinas (Org.). Lo Multidisciplinario del Antes y Después del Covid-19. Ciudad de México: Thomson Reuters, 2020. (ISBN 978-607-474-571-9). Available at SSRN: https://ssrn.com/abstract=3680205 
some to interpret the rule so that it could go as far as allowing the recommendation of data surveillance of mobile phones to track the movement of contaminated individuals and indicate the people with whom they had contact. (South Korea has adopted this strategy. ${ }^{22-23}$ Nevertheless, the IHR also provides limits to which restrictions may be imposed by States on the grounds of pandemic protection. Thus, while Article 31 allows States to require medical examinations, vaccination, or other prophylactic means to allow foreign nationals into their territories, ${ }^{24}$ Article 32 demands that, while implementing such actions, States do not forfeit human dignity, human rights, and fundamental freedoms. ${ }^{25}$ Likewise, even if it does not expressly state this, it seems clear that unfounded discrimination is invalid before the IHR ${ }^{26}$ Similarly, the IHR does not prohibit the adoption by States of additional health measures, i.e., measures beyond those recommended by the WHO. Nevertheless, States must report the measures to the organization and, in these reports, must justify the seriousness of the measures adopted. At this point, it is necessary to highlight that the current regulations emphasize that such justifications must be based on scientific data interpreted based on scientific

organization" (translated). CONFORTI, Benedetto. Diritto Internazionale. $\mathbf{6}^{\mathbf{a}}$ ed. Napoli: Editoriale Scientifica, 2002.

${ }^{22}$ VON BOGDANDY, Armin; VILLARREAL, Pedro. International Law on Pandemic Response: A First Stocktaking in Light of the Coronavirus Crisis. Rochester, NY: Social Science Research Network, 2020b. p. 8-9.

23 "The South Korean government says the public is more likely to trust it if it releases transparent and accurate information about the virus, including travel histories of confirmed patients. Laws passed since the country's last major disease outbreak, of Middle East respiratory syndrome (MERS) in 2015, now specifically allow authorities to publish this information. Numerous websites and smartphone apps have also sprung up to collect and map the data, [...]. Experts and the World Health Organization say that South Korea's extensive tracing, testing and isolation measures - along with campaigns encouraging people to avoid large gatherings - have helped to reduce the virus's spread." ZASTROW, Mark. South Korea is reporting intimate details of COVID-19 cases: has it helped? Nature. 2020.

${ }^{24}$ IHR, Article 31.

${ }^{25}$ IHR, Article 32.

${ }^{26}$ VON BOGDANDY; VILLARREAL, International Law on Pandemic Response, p. 9.

MENEZES, Wagner; MARCOS, Henrique. International Law Post-Pandemic. In: Gonzalo Levi Obregón Salinas (Org.). Lo Multidisciplinario del Antes y Después del Covid-19. Ciudad de México: Thomson Reuters, 2020. (ISBN 978-607-474-571-9). Available at SSRN: https://ssrn.com/abstract=3680205 
principles and expressed through scientific evidence that demonstrates the correlation of such measures to health promotion. ${ }^{27}$

In the light of its technical-scientific vocation, the WHO's bodies shall guide their decision-making process in an informed manner by data, whether official or not ("governance for information"). To this end, each Member State must structure a health system capable of efficiently providing adequate reports for the WHO's supervision purposes. This duty stands out in particular when considering that the WHO is dependent on data provided by States and third parties and does not have its own system for obtaining information. ${ }^{28}$ The IHR allows the WHO to make use of documents formally produced by the Member States and those informal sources and even those provided by one Member State in relation to another. ${ }^{29-30}$ International cooperation with intergovernmental and international organizations is cardinal to WHO action. The WHO must guide its action in a coordinated manner with the other international organizations, agencies, and entities that compose the United Nations family. This way, if its action is under the competence of another entity, the WHO should seek means to coordinate its strategy so that the application of the necessary measures to promote global health is assured. According to the IHR, no clause in the regulation should be interpreted in such a way as to limit the WHO's powers in achieving its mission. ${ }^{31}$

In general, the extent of the organization's powers reflects the trust of the international community in the technical-scientific decisions made by the body of experts who are WHO agents. Consequently, it can be inferred that it is a recurring concern of the organization not to be considered a politically directed entity but based on scientific motivations and justifications. Nevertheless, historically, the WHO has not been able to entirely escape the Cold War's polarization. The organization had always been accused

\footnotetext{
${ }^{27}$ IHR, Article 43.

${ }^{28}$ IHR, Articles 6 and 7.

${ }^{29}$ IHR, Article 9.

${ }^{30}$ IHR, Article 10.

${ }^{31}$ IHR, Article 14.
}

MENEZES, Wagner; MARCOS, Henrique. International Law Post-Pandemic. In: Gonzalo Levi Obregón Salinas (Org.). Lo Multidisciplinario del Antes y Después del Covid-19. Ciudad de México: Thomson Reuters, 2020. (ISBN 978-607-474-571-9). Available at SSRN: https://ssrn.com/abstract=3680205 
of "choosing sides," favoring at first what could be considered a socialist perspective for public health promotion. In the 1990s, on the other hand, the WHO shifted its focus to health promotion through private sector providers. This decision was also severely criticized. Thus, over the years, the WHO remained active but progressively ceased to play the leading role on the frontline of crises, preferring to act discreetly behind the scenes. ${ }^{32}$ Regardless, it does not seem that the organization has succeeded in escaping criticism for its stance towards COVID-19.

\section{WESTPHALIA LIVES?}

The rise of a State's patriotism is a phenomenon that usually accompanies or may even be considered to be co-responsible for hindering the process of international legal integration. In other words, national strengthening sometimes accompanies the adoption of isolationist postures and mistrust of the "other" (being understood as an individual or community that does not share the exact patriotic identity). Based on this interpretation, some voices see the current conservative turn as the reason for the various recent political positions that have led to the retraction of the global integration project. ${ }^{33}$ The situation reflects the Westphalian paradigm of sovereignty and international relations. The three complementary treaties - the "Peace of Münster," the Treaty of Münster, and the Treaty of Osnabrück - signed at the end of the Thirty Years War in the 17th century coined the "Peace of Westphalia." Its two main legacies are (i) the secularization of the State and (ii) the affirmation of the model of State sovereignty based on the mutual respect for the internal regulation of national governments, i.e., the primacy of non-

${ }^{32}$ VON BOGDANDY; VILLARREAL, International Law on Pandemic Response, p. 5.

${ }^{33}$ MARCOS, Henrique Jerônimo Bezerra. O Patriotismo Constitucional enquanto Instrumento de Cooperação e Integração Jurídica Internacional, In: MENEZES, Wagner (Org.). Direito Internacional em Expansão - Volume XVII. Belo Horizonte: Arraes Editores, 2019.

MENEZES, Wagner; MARCOS, Henrique. International Law Post-Pandemic. In: Gonzalo Levi Obregón Salinas (Org.). Lo Multidisciplinario del Antes y Después del Covid-19. Ciudad de México: Thomson Reuters, 2020. (ISBN 978-607-474-571-9). Available at SSRN: https://ssrn.com/abstract=3680205 
intervention. Its legacy enshrined the State as the cornerstone of international relations. ${ }^{34-}$ $35-36$

It can be argued that the Westphalian model has been legally overtaken in the face of the new rationale that guides contemporary International Law. Normatively, at least, the classical model of sovereignty no longer has the same space as before. ${ }^{37}$ It is no longer legally valid to argue in defense of a perspective of the absolute sovereignty of States in the light of the International Law now in force. As already pointed out in the "Section" above, contemporary international society lives under another architecture where the State increasingly loses their position as the sole actor on the stage, being forced to share their performance with other subjects. Slowly, the legal protagonism moves from State sovereignty to concerns with international human rights law, both in individual and collective view. ${ }^{38-39}$ That includes the structuring of international tools specifically aimed at safeguarding people's rights, such as international human rights courts. ${ }^{40-41}$ In addition, international jus cogens standards also call into question any legal

${ }^{34}$ VIGNALI, Heber Arbuet. Derecho Internacional publico: temas de la teoría general. Montevidéo: Talleres grafico, 1993.

${ }^{35}$ MARCOS, Henrique Jerônimo Bezerra. A Apreciação Judicial dos Atos do Conselho de Segurança pela Corte Internacional de Justiça em uma Perspectiva Kelseniana. Dissertação de Mestrado (Ciências Jurídicas), Universidade Federal da Paraíba (UFPB), Centro de Ciências Jurídicas (CCJ), João Pessoa, 2018.

${ }^{36}$ GROSS, Leo. The Peace of Westphalia, 1648-1948. The American Journal of International Law. v. 42, n. 1, p. 20-41, 1948.

${ }^{37}$ TRINDADE, Antônio Augusto Cançado. International Law for Humankind: Towards a New Jus Gentium. Leiden: Martinus Nijhoff Publishers, 2010.

${ }^{38}$ BOBBIO, Norberto. A Era dos Direitos. 7. ed. Rio de Janeiro: Elsevier, 2004.

${ }^{39}$ DRNAS DE CLÉMENT, Z. The Humanisation of International Courts In: VUKAS, Budislav; ŠOŠIĆ, Trpimir (Org.). International Law: New Actors, New Concepts, Continuing Dilemmas: Liber amicorum Božidar Bakotić. Leiden: Brill, 2010, pp. 397-408.

${ }^{40}$ MENEZES, Wagner. Tribunais Internacionais: Jurisdição e Competência. São Paulo: Saraiva, 2013. p. 78.

${ }^{41}$ CASSIDY, Julie. Emergence of the Individual as an International Juristic Entity: Enforcement of International Human Rights. Deakin Law Review, v. 9, n. 2, p. 533-572, 2004.

MENEZES, Wagner; MARCOS, Henrique. International Law Post-Pandemic. In: Gonzalo Levi Obregón Salinas (Org.). Lo Multidisciplinario del Antes y Después del Covid-19. Ciudad de México: Thomson Reuters, 2020. (ISBN 978-607-474-571-9). Available at SSRN: https://ssrn.com/abstract=3680205 
interpretation that attempts to rescue an absolute vision of State sovereignty. ${ }^{42-43}$ After all, according to Article 53 of the Vienna Convention on the Law of Treaties, the essential characteristic of these norms is that no State can evade them, and they cannot be altered by State will. Therefore, it is not enough for a single State or even a group of States to have the will to change these norms. For a jus cogens rule to be derogated, the international community as a whole must act so that a second jus cogens rule may be created to substitute the antecedent. ${ }^{44-45}$

Leaving the normative field, however, by geopolitically examining the reaction of some States to the international behavior of the COVID-19 pandemic, it is noticeable how some vestiges of the Westphalian paradigm persist. Following the line of accusations of political alignment made in the past, the WHO has been the target of mistrust in the context of the problematic relationship between the United States of America (US) and the People's Republic of China (PRC).

Although there is still ${ }^{46}$ no definitive proof (and some sources even point to the opposite) ${ }^{47}$ there are strong indications that the new coronavirus originated in China's territory, specifically in the city of Wuhan, Hubei province. It was in the PRC where the first cases of the disease were diagnosed in December 2019. The suspicions are that the virus has bats as its stationary hosts (natural reservoirs) that have transmitted the virus to other animals (intermediate hosts), which are sold in the markets of the region and indirectly ended up infecting the first people. ${ }^{48}$

\footnotetext{
${ }^{42}$ WALTERMANN, Antonia. Reconstructing Sovereignty. Cham: Springer, 2019.

${ }^{43}$ DUPUY, Pierre-Marie. L'Unité de L'Ordre Juridique International. Cours Général de Droit International Public. v. 297, n. 9, p. 9-490, 2002. p. 311.

${ }^{44}$ KELSEN, Hans. Principles of International Law. New York: Rinehart \& Company, 1952. p. 344 .

${ }^{45}$ SHAW, Malcolm N. International Law. 8. ed. New York: Cambridge University Press, 2017. p. $91-93$.

${ }^{46}$ This text was finalized in June 2020.

${ }^{47}$ BEAUMONT, Peter. Where did Covid-19 come from? What we know about its origins. The
} Guardian. 2020.

${ }^{48}$ ANDERSEN, Kristian G. et al. The Proximal Origin of SARS-CoV-2. Nature Medicine. v. 26, n. 4 , p. $450-452,2020$.

MENEZES, Wagner; MARCOS, Henrique. International Law Post-Pandemic. In: Gonzalo Levi Obregón Salinas (Org.). Lo Multidisciplinario del Antes y Después del Covid-19. Ciudad de México: Thomson Reuters, 2020. (ISBN 978-607-474-571-9). Available at SSRN: https://ssrn.com/abstract=3680205 
Chinese authorities reported the new coronavirus to the WHO on December 31, 2019. On that occasion, the WHO publicly announced that there was no evidence that the virus could be transmitted between people ${ }^{49}$. As is well known, however, this prospect had been refuted by the accelerated spread of the virus, which was even transmitted by people who did not ostensibly present symptoms ${ }^{50}$. Nevertheless, at the time, the WHO applauded the PRC's stance in the treatment of COVID-19, expressly pointing out that the swift Chinese response helped the entire world to resist the pandemic better:

\begin{abstract}
"We are encouraged that the steps China has taken to contain the outbreak at its source appear to have bought the world time, even though those steps have come at greater cost to China itself. But it's slowing the spread to the rest of the world. We're encouraged that outside China, we have not yet seen widespread community transmission. We're encouraged that the global research community has come together to identify and accelerate the most urgent research needs for diagnostics, treatments and vaccines. We're encouraged that we have been able to ship diagnostic kits, as well as supplies of masks, gloves, gowns and other personal protective equipment to some of the countries that need it most. We're encouraged that an international team of experts is now on the ground in China, working closely with their Chinese counterparts to understand the outbreak, and to inform the next steps in the global response." ${ }^{151}$
\end{abstract}

Such praise has been poorly received by the US and part of the Western world. ${ }^{52}$ In addition to political and ideological differences, the US, through its Department of Homeland Security (DHS), accused China of maliciously omitting information from the WHO, minimizing the severity of the disease and hiding data that showed that the PRC

${ }^{49}$ WHO, World Health Organization. Pneumonia of Unknown Cause - China, World Health Organization, Available at: <http://www.who.int/csr/don/05-january-2020-pneumonia-ofunkown-cause-china/en/>, Accessed on 9 jun. 2020.

${ }^{50}$ ORAN, Daniel P.; TOPOL, Eric J. Prevalence of Asymptomatic SARS-CoV-2 Infection. Annals of Internal Medicine. 2020.

${ }^{51}$ WHO, World Health Organization. Munich Security Conference, World Health Organization, 15 February $2020 . \quad$ Available at: $<$ https://www.who.int/dg/speeches/detail/munich-security-conference>, accessed on: 9 jun. 2020.

${ }^{52}$ VON BOGDANDY; VILLARREAL, Critical Features of International Authority in Pandemic Response, p. 22-23.

MENEZES, Wagner; MARCOS, Henrique. International Law Post-Pandemic. In: Gonzalo Levi Obregón Salinas (Org.). Lo Multidisciplinario del Antes y Después del Covid-19. Ciudad de México: Thomson Reuters, 2020. (ISBN 978-607-474-571-9). Available at SSRN: https://ssrn.com/abstract=3680205 
already knew that human-to-human transmission was possible. ${ }^{53}$ Preliminary research conducted through analysis of vehicular traffic satellite images and keywords researched in China's largest online search engine ("baidu.com") point to the possibility that the pandemic may have started in August 2019, i.e., months before PRC officially informed the WHO about the new virus. ${ }^{54}$ Also, in May 2020, according to a joint announcement of the Federal Bureau of Investigation (FBI) and the Cybersecurity and Infrastructure Security Agency (CISA), preliminary investigations indicate that there has been illicit action by cyber terrorists affiliated with the Chinese government in specific virtual attacks carried out against public health research centers related to COVID-19. According to US agencies, these groups attempted to access virus-related data protected by copyright. ${ }^{55}$

Regardless of these accusations' veracity, it is not difficult to understand why the WHO's praise of China is maligned by the US and its close partners. President Donald Trump accused China of concealing relevant information from the WHO,

53 "U.S. officials believe China covered up the extent of the coronavirus outbreak - and how contagious the disease is - to stock up on medical supplies needed to respond to it, intelligence documents show. Chinese leaders "intentionally concealed the severity" of the pandemic from the world in early January, according to a four-page Department of Homeland Security intelligence report dated May 1 and obtained by The Associated Press. The revelation comes as the Trump administration has intensified its criticism of China, with Secretary of State Mike Pompeo saying Sunday that that country was responsible for the spread of disease and must be held accountable." WEISSERT, Will. DHS report: China hid virus' severity to hoard supplies, AP NEWS, Available at: <https://apnews.com/bf685dcf52125be54e030834ab7062a8>, Accessed on 9 jun. 2020.

${ }^{54}$ NSOESIE, Elaine Okanyene et al. Analysis of Hospital Traffic and Search Engine Data in Wuhan China indicates Early Disease activity in the Fall of 2019. Cambridge: Harvard Medical School, 2020.

55 "The FBI is investigating the targeting and compromise of U.S. organizations conducting COVID-19-related research by PRC-affiliated cyber actors and non-traditional collectors. These actors have been observed attempting to identify and illicitly obtain valuable intellectual property (IP) and public health data related to vaccines, treatments, and testing from networks and personnel affiliated with COVID-19-related research. The potential theft of this information jeopardizes the delivery of secure, effective, and efficient treatment options." FBI, Federal Bureau of Investigation; CISA, Cybersecurity and Infrastructure Security Agency. People's Republic of China (PRC) Targeting of COVID-19 Research Organizations. Public Service Announcement (Unclassified). 2020.

MENEZES, Wagner; MARCOS, Henrique. International Law Post-Pandemic. In: Gonzalo Levi Obregón Salinas (Org.). Lo Multidisciplinario del Antes y Después del Covid-19. Ciudad de México: Thomson Reuters, 2020. (ISBN 978-607-474-571-9). Available at SSRN: https://ssrn.com/abstract=3680205 
neglecting the whole world for not revealing what they knew about COVID-19 at the outset. Finally, Trump pointed out that the Chinese stance was responsible for a "mass worldwide killing." ${ }^{56}$ The criticism of the US Head of State was also directed against the WHO, accusing it of being "a puppet of China" and also responsible for the uncontrolled advance of the pandemic. ${ }^{57}$ In a letter from the US President to WHO Director-General Tedros Adhanom Ghebreyesus, the White House reports that it has suspended funding to WHO and will conduct an investigation in the face of the "failure" of the international organization to deal with the pandemic. According to the text signed on 18 May 2020, in addition to ignoring reliable reports dating back to December 2019 - which since then have shown that the virus was transmissible between people - the WHO was unable to act independently, investigating evidence that conflicted with the interests of the Chinese government. ${ }^{58}$ Throughout its pages, the document points out what (in the

${ }^{56}$ SOMERVILLE, Ewan. Donald Trump accuses China of "mass worldwide killing" over virus, Evening Standard, Available at: <https://www.standard.co.uk/news/world/donaldtrump-china-coronavirus-a4446286.html >, Accessed on 10 jun. 2020.

${ }^{57}$ BBC. Trump accuses WHO of being a "puppet of China," BBC News, Available at: $<$ https://www.bbc.com/news/health-52679329>, Accessed on 10 jun. 2020.

58 " [...] The World Health Organization consistently ignored credible reports of the virus spreading in Wuhan in early December 2019 or even earlier, including reports from the Lancet medical journal. The World Health Organization failed to independently investigate credible reports that conflicted directly with the Chinese government's official accounts, even those that came from sources within Wuhan itself. By no later than December 30, 2019, the World Health Organization office in Beijing knew that there was a "major public health" concern in Wuhan. Between December 26 and December 30, China's media highlighted evidence of a new virus emerging from Wuhan, based on patient data sent to multiple Chinese genomics companies. Additionally, during this period, Dr. Zhang Jixian, a doctor from Hubei Provincial Hospital of Integrated Chinese and Western Medicine, told China's health authorities that a new coronavirus was causing a novel disease that was, at the time, afflicting approximately 180 patients. [...] On January 14, 2020, the World Health Organization gratuitously reaffirmed China's now-debunked claim that the coronavirus could not be transmitted between humans, stating: "Preliminary investigations conducted by the Chinese authorities have found no clear evidence of human-to-human transmission of the novel coronavirus (2019-nCov) identified in Wuhan, China." This assertion was in direct conflict with censored reports from Wuhan. On January 21, 2020, President Xi Jinping of China reportedly pressured you not to declare the coronavirus outbreak an emergency. You gave in to this pressure the next day and told the world that the coronavirus did not pose a Public Health Emergency of International Concern. Just over one week later, on January 30, 2020,

MENEZES, Wagner; MARCOS, Henrique. International Law Post-Pandemic. In: Gonzalo Levi Obregón Salinas (Org.). Lo Multidisciplinario del Antes y Después del Covid-19. Ciudad de México: Thomson Reuters, 2020. (ISBN 978-607-474-571-9). Available at SSRN: https://ssrn.com/abstract=3680205 
US President's view) was the WHO's irresponsible behavior and that, alongside China, it is responsible for the tragedy. In the text, the US President gives the deadline of thirty days for the WHO to demonstrate independence and change its position. Otherwise, the US will denounce the organization's treaty and cease to be part of the WHO. ${ }^{59}$

The US President's allegations are not a consensus among other world leaders. It is also possible to point out some apparent inconsistencies in the data raised by the White House. ${ }^{60}$ Nevertheless, the demonstrations were sufficient to raise the debate on China's international liability for alleged violations of Articles 6 and 7 of the IHR (referred to in the previous "Section") for failure to meet synchronous reporting obligations and proper sharing of relevant information. ${ }^{61}$ According to some, it would be possible for any State to invoke the jurisdiction of the International Court of Justice (ICJ) to claim reparation for damage caused by the PRC in light of Article 75 of the WHO Constitution, ${ }^{62}$ by providing that conflicts relating to the interpretation of the said treaty that are not resolved by negotiations or the Health Assembly will be submitted to the ICJ (subject to the parties' agreement defining another mode of solution). That is a

overwhelming evidence to the contrary forced you to reverse course. [...]" TRUMP, Donald J. Donald J. Trump (@realDonaldTrump) on Twitter: "This is the letter sent to Dr. Tedros of the World Health Organization. It is self-explanatory! https://t.co/pF2kzPUpDv" / 11:55 PM, May 18, 2020, Twitter for iPhone, Twitter, Available at: <https://twitter.com/realDonaldTrump/status/1262577580718395393>, Accessed on 10 jun. 2020.

${ }^{59}$ HINDUSTAN TEAMS. 'The only way forward for WHO is...': Full text of Trump's letter to WHO chief, Hindustan Times, Available at: $<$ https://www.hindustantimes.com/world-news/the-only-way-forward-for-the-who-is-full-text-oftrump-s-letter-to-who-chief-tedros-adhanom-ghebreyesus/story-

MCee8MiYg9NYh7gPcYMGRO.html>, Accessed on 10 jun. 2020.

${ }^{60}$ SCIENCE MEDIA CENTER. Expert Reaction to Letter sent from Donald Trump to Dr. Tedros Adhanom, Director-General of the WHO, SMC, Science Media Center, Available at: <https://www.sciencemediacentre.org/expert-reaction-to-letter-sent-from-donaldtrump-to-dr-tedros-adhanom-director-general-of-the-who/>, Accessed on 10 jun. 2020.

${ }^{61}$ TZENG, Peter. Taking China to the International Court of Justice over COVID-19. European Journal of International Law, EJIL: Talk! 2020.

${ }^{62}$ WHO Constitution, Article 75.

MENEZES, Wagner; MARCOS, Henrique. International Law Post-Pandemic. In: Gonzalo Levi Obregón Salinas (Org.). Lo Multidisciplinario del Antes y Después del Covid-19. Ciudad de México: Thomson Reuters, 2020. (ISBN 978-607-474-571-9). Available at SSRN: https://ssrn.com/abstract=3680205 
speculative alternative and, like any other matter, is subject to various legal analyses and interpretations based on competence and jurisdiction under International Law. ${ }^{63}$

On the other hand, the American stance is not immune to criticism either. Some complaints from the Federal Republic of Germany and the French Republic accuse the US of "piracy" for confiscating thousands of "n95" medical masks directed to Western Europe and Canada. ${ }^{64}$ The US, however, denies the accusations. ${ }^{65}$ These charges come in the context of the US Department of Defense's first "Defense Production Act Title 3" concerning the pandemic, with an investment of $\$ 133$ million for the production of medical masks to meet US domestic needs. ${ }^{66}$ Also, the White House expressly requested "3M" to stop exporting US-made respirators to the Canadian and Latin American markets. ${ }^{67-68}$ Also, astonishingly, some European politicians claim that President Trump offered one billion dollars to the German bio-pharmaceutical "CureVac" to guarantee a vaccine exclusively for the United States. The pharmaceutical declined the proposal. Recognizing the global relevance of the vaccine, its representatives said it was outrageous

${ }^{63}$ KARAGIANNIS, Syméon. La Multiplication des Juridictions Internationales: Un Système Anarchique? In: SOCIETE FRANÇAISE POUR LE DROIT INTERNATIONAL (Org.). Colloque de Lille: La Juridictionnalisation du Droit International. Paris: A. Pedone, 2003.

${ }^{64}$ DEUTSCHE WELLE. US accused of seizing face mask shipments bound for Europe, Canada | DW | 03.04.2020, DW.COM, Available at: <https://www.dw.com/en/us-accusedof-seizing-face-mask-shipments-bound-for-europe-canada/a-53010923>, Accessed on 10 jun. 2020.

${ }^{65}$ DEUTSCHE WELLE. US firm denies German "piracy" claims over vanished face masks | DW | 04.04.2020, DW.COM, Available at: <https://www.dw.com/en/us-firm-deniesgerman-piracy-claims-over-vanished-face-masks/a-53017112>, Accessed on 10 jun. 2020.

${ }^{66}$ DOD, Department of Defense of the United States of America. First DOD Defense Production Act Title 3 COVID-19 Project, U.S. Department of Defense, Available at: $<$ https://www.defense.gov/Newsroom/Releases/Release/Article/2146692/first-dod-defenseproduction-act-title-3-covid-19-project/>, Accessed on 10 jun. 2020.

${ }^{67}$ 3M. 3M Response to Defense Production Act Order, 3M News, United States, Available at: $\quad<$ https://news.3m.com/press-release/company-english/3m-response-defense-production-actorder $>$, Accessed on 4 apr. 2020.

${ }^{68}$ ABEDI, Maham. Coronavirus: Trump asks medical supply firm 3M to stop selling N95 respirators to Canada, Global News, Available at: <https://globalnews.ca/news/6772979/coronavirus-3m-n95-respirators-trump-canada/>, Accessed on 3 apr. 2020.

MENEZES, Wagner; MARCOS, Henrique. International Law Post-Pandemic. In: Gonzalo Levi Obregón Salinas (Org.). Lo Multidisciplinario del Antes y Después del Covid-19. Ciudad de México: Thomson Reuters, 2020. (ISBN 978-607-474-571-9). Available at SSRN: https://ssrn.com/abstract=3680205 
to restrict access to the drug, especially given the global impact of COVID- $19{ }^{69}$ The German politician, Karl Lauterbach, firmly stated: "Capitalism has limits."70

Down South, inspired by the White House's stance, the President of the Federative Republic of Brazil, Jair Bolsonaro, says he is also considering denouncing Brazil's membership in the WHO, accusing it of an "ideological bias" favorable to China. ${ }^{71}$ The escalation of Chinese-Brazilian tension has reached the point where the Brazilian Minister of Education, Abraham Weintraub, accused the PRC of having armed the entire global pandemic to carry out its plan to "dominate the world." The Minister of Foreign Affairs, Ernesto Araújo, also published a text in which he assumedly intends to reveal the "communist-globalist" strategy of transforming the pandemic into a subversion of democracy and mass enslavement of human beings. ${ }^{72}$ At the same time, along the lines of President Trump, the Brazilian government has disregarded the risks of COVID-19 by criticizing social isolation and quarantine adopted around the world. The result is that, in addition to being ideologically aligned with the US, Brazil shares with the United States the podium of the first two places in the number of confirmed cases of the disease and the number of deaths by COVID-19 (see "Table 01").

${ }^{69}$ OLTERMANN, Philip. Coronavirus: anger in Germany at report Trump seeking
exclusive vaccine deal, The Guardian, Available at: $<$ https://www.theguardian.com/world/2020/mar/16/not-for-sale-anger-in-germany-at-reporttrump-seeking-exclusive-coronavirus-vaccine-deal>, Accessed on 10 jun. 2020. 70." "Capitalism has limits" (free translation). BUTLER, Judith. Capitalism Has its Limits, Verso, Available at: <https://www.versobooks.com/blogs/4603-capitalism-has-its-limits>, Accessed on 17 jun. 2020.

${ }^{71}$ REUTERS. Bolsonaro calls WHO "political," threatens Brazil exit, Reuters World News, Available at: <https://www.reuters.com/article/us-health-coronavirus-brazil-bolsonaroidUSKBN23C353>, Accessed on 10 jun. 2020.

72 ARAUJO, Ernesto. Chegou o Comunavírus, Metapolítica 17, Available at: $<$ https://www.metapoliticabrasil.com/post/chegou-o-comunavírus $>$, Accessed on 15 jun. 2020.

MENEZES, Wagner; MARCOS, Henrique. International Law Post-Pandemic. In: Gonzalo Levi Obregón Salinas (Org.). Lo Multidisciplinario del Antes y Después del Covid-19. Ciudad de México: Thomson Reuters, 2020. (ISBN 978-607-474-571-9). Available at SSRN: https://ssrn.com/abstract=3680205 
Table 01: WHO COVID-19 panel on 15 June 2020

\begin{tabular}{|c|c|c|c|}
\hline State & N. ${ }^{o}$ of Confirmed Cases & State & N. ${ }^{o}$ of Deaths \\
\hline 1st USA & 2.057 .838 & 1st USA & 115.112 \\
\hline 2nd Brazil & 850.514 & 2nd Brazil & 42.270 \\
\hline 3rd Russia & 528.964 & $\begin{array}{l}\text { 3rd United } \\
\text { Kingdom }\end{array}$ & 41.662 \\
\hline 4th India & 332.424 & 4th Italy & 34.301 \\
\hline $\begin{array}{l}\text { 5th United } \\
\text { Kingdom }\end{array}$ & 294.379 & 5th France & 29.335 \\
\hline 6th Spain & 243.605 & 6th Spain & 27.136 \\
\hline 7th Italy & 236.651 & 7th Mexico & 16.872 \\
\hline$\ldots$ & $\ldots$ & $\ldots$ & $\ldots$ \\
\hline World Total & 7.805 .148 & World Total & 431.192 \\
\hline
\end{tabular}

Source: World Health Organization. ${ }^{73}$

Despite the apparent political coordination (and even the choice of drug as a panacea for the pandemic), ${ }^{74}$ Brazil has been the target of criticism from the US. President Trump severely rebuked Brazil's stance on the pandemic, revealing that, in his opinion, if the US had adopted measures similar to Brazil's, the US would have lost more than a million lives. ${ }^{75}$ Further, the US is studying to implement restrictions on the entry

${ }^{73}$ WHO, World Health Organization. WHO Coronavirus Disease (COVID-19) Dashboard, World Health Organization, Available at: <https://covid19.who.int/>, Accessed on 15 jun. 2020.

${ }^{74}$ JAPAN TIMES. Like Trump, Brazil's Jair Bolsonaro also bets big on chloroquine, The Japan Times, Available at: <https://www.japantimes.co.jp/news/2020/05/21/world/braziljair-bolsonaro-hydroxychloroquine/>, Accessed on 11 jun. 2020.

${ }^{75}$ SARAIVA, Augusta. Trump: Brazil having "a very hard time" with coronavirus, The Brazilian Report, Available at: <https://brazilian.report/coronavirus-brazil-liveblog/2020/06/05/trump-brazil-having-a-very-hard-time-with-coronavirus/>, Accessed on 15 jun. 2020.

MENEZES, Wagner; MARCOS, Henrique. International Law Post-Pandemic. In: Gonzalo Levi Obregón Salinas (Org.). Lo Multidisciplinario del Antes y Después del Covid-19. Ciudad de México: Thomson Reuters, 2020. (ISBN 978-607-474-571-9). Available at SSRN: https://ssrn.com/abstract=3680205 
into US territory of anyone who has been in Brazilian territory. ${ }^{76}$ Finally, as a measure that seems to unequivocally reveal the terms of the relationship between these States, a cargo of Chinese respirators purchased by Brazil and destined for Bahia was diverted for local use in the US after a stopover in Florida. The US denies having purchased or blocked Brazilian cargo, but, until now, the material that should be delivered to Brazil has not entered its territory. ${ }^{77}$

Still in Latin America, despite being politically opposed to President Bolsonaro and President Trump, the President of the United Mexican States, Andrés Manuel López Obrador, ends up joining the American and Brazilian stance before the pandemic by also assuming a populist stance that denyies the seriousness of the disease. Likewise, the three Presidents share the disregard for the use of protective masks; Latin American leaders continue to participate in rallies where they physically approach massive groups of supporters - disregarding WHO instructions to prevent the proliferation of COVID-19 in agglomerations. ${ }^{78}$

It seems that the denial of these leaders is not so much an expression of skepticism about the best practices to be adopted in the fight against the pandemic, but a remorseless concern for the economic growth of their States with immediate electoral consequences. Illustratively, about the measures of quarantine, social isolation, and, above all, the closing of trade, the Brazilian President repeatedly expressed his view that such measures could not be more grave than the pandemic itself. ${ }^{79}$ In other words, according to President Bolsonaro's interpretation, it would be necessary to rethink the

${ }^{76}$ DUGYALA, Rishika. Trump places travel restrictions on Brazil, POLITICO, Available at: <https://www.politico.com/news/2020/05/24/trump-travel-restrictions-brazil-277633>, Accessed on 15 jun. 2020.

${ }^{77}$ PARAGUASSU, Lisandra. U.S. denies hijacking Chinese medical supplies meant for Brazil, Reuters, Available at: <https://www.reuters.com/article/us-health-coronavirus-brazilusa-idUSKBN21P315>, Accessed on 15 jun. 2020.

${ }^{78}$ BLOFIELD, Merike; HOFFMANN, Bert; LLANOS, Mariana. Assessing the Political and Social Impact of the COVID-19 Crisis in Latin America. GIGA Focus, Latin America. v. 3, 2020. p. 4 .

${ }^{79}$ Ibid.

MENEZES, Wagner; MARCOS, Henrique. International Law Post-Pandemic. In: Gonzalo Levi Obregón Salinas (Org.). Lo Multidisciplinario del Antes y Después del Covid-19. Ciudad de México: Thomson Reuters, 2020. (ISBN 978-607-474-571-9). Available at SSRN: https://ssrn.com/abstract=3680205 
scale of merit of the lives lost by the disease given the harmful economic impact that such health measures could have on the Brazilian economy.

Leaving aside the moral analysis, the ideological foundation of the arguments for maintaining national economic activity amid the global pandemic reveals a dysfunctional view of how globalized Markets work. Even if, for whatever reason, the pandemic was not taking Latin American lives as severely as it did in North America, Europe, and Asia, the Brazilian or Mexican economy would not be exempt from the impact of the global recession that will probably come as a reaction to COVID-19. Thus, the narrow-mindedness of the aforementioned Latin American leaders seems to prevent them from seeing that, regardless of whether or not local businesses close, their eminently commodity-based economy will be affected by the upcoming storm. Such a perspective reveals an unconscious ideological understanding that views each State as a bastion entrenched in its national sovereignty. Preliminary signs point in the opposite direction.

Only in the first month after the outbreak of COVID-19, Brazil suffered capital outflow equivalent to Nicaragua's gross domestic product. In the same period, the Brazilian Real lost twenty percent of its value against the US dollar. ${ }^{80}$ The situation in the rest of Latin America is not promising. Its economies are dependent on the demands of the "Global North." As long as the industrialized markets remain in "crisis mode," Latin America will suffer. In what seems like a satire, one of the possible hopes for avoiding economic collapse comes from China. The PRC, which suffered the pandemic's effects before the rest of the world, will probably be one of the first to succeed in rebuilding its post-pandemic economy. Thus, while Europe and North America are closing their doors to avoid the second wave of COVID-19, Latin America may have to become even more dependent on Asian markets. ${ }^{81}$

The internationalization of the economic order in the monetary, financial and commercial fields by the "Bretton Woods tripod" — the International Monetary Fund

\footnotetext{
${ }^{80}$ Ibid., p. 7.

${ }^{81}$ Ibid., p. 7-9.
}

MENEZES, Wagner; MARCOS, Henrique. International Law Post-Pandemic. In: Gonzalo Levi Obregón Salinas (Org.). Lo Multidisciplinario del Antes y Después del Covid-19. Ciudad de México: Thomson Reuters, 2020. (ISBN 978-607-474-571-9). Available at SSRN: https://ssrn.com/abstract=3680205 
(IMF), the International Bank for Reconstruction and Development (IBRD) and the World Trade Organization (WTO) — establishes a new reality of globalization for national economies. ${ }^{82-83}$ Similar to what has already been discussed above, here we can also see the multiplication of new actors that, together with the States, assume a central role in the world economic scenario, such as international organizations and transnational companies. Nevertheless, in this globalizing process of strengthening the presence of internationalized capital, the weakening of State borders takes the opposite path. Extranational institutions increasingly impose economic norms in international forums. Moreover, the hardening of central capitalist economies makes peripheral economies even more dependent..$^{84-85}$

Recognizing the relevance of these international economic institutions' role, the IMF held a press conference alongside the WHO. At their joint event in April 2020, Kristalina Gueorguieva, Managing Director of the IMF, and the Managing Director of the WHO recognized the importance of the two organizations' contiguous work. The WHO to help protect people's health and the IMF in the health of the global economy. They called for joint action in these two areas: The economy and public health go hand in hand. At this critical moment, a balance must be prioritized, especially in emerging

${ }^{82}$ MENEZES, Wagner. Ordem Global e Transnormatividade. Ijuí: Editora Unijuí, 2005. p. 77 et seq.

${ }^{83}$ MENEZES, Tribunais Internacionais: Jurisdição e Competência, p. 79.

${ }^{84}$ FRIEDMANN, Wolfgang. Mudança de Estrutura no Direito Internacional. Rio de Janeiro: Livraria Freitas Bastos, 1971. p. 25-26.

${ }^{85}$ Similarly, Peter Singer: "Global market forces provide incentives for every nation to put on what Thomas Friedman has called 'a Golden Strait- jacket,' a set of policies that involve freeing up the private sector of the economy, shrinking the bureaucracy, keeping inflation low, and removing restrictions on foreign investment. If a country refuses to wear the Golden Straitjacket, or tries to take it off, then the electronic herd - the currency traders, stock and bond traders, and those who make investment decisions for multinational corporations - could gallop off in a different direction, taking with it the investment capital that countries want to keep their economy growing. When capital is internationally mobile, to raise your tax rates is to risk triggering a flight of capital to other countries with comparable investment prospects and lower taxation." SINGER, Peter. One World: The Ethics of Globalization. New Haven: Yale University Press, 2002. p. 10-11.

MENEZES, Wagner; MARCOS, Henrique. International Law Post-Pandemic. In: Gonzalo Levi Obregón Salinas (Org.). Lo Multidisciplinario del Antes y Después del Covid-19. Ciudad de México: Thomson Reuters, 2020. (ISBN 978-607-474-571-9). Available at SSRN: https://ssrn.com/abstract=3680205 
and developing markets, which, in addition to economic fragility, are often those with the worst public health systems. Thus, the organizations have emphasized that "saving lives or saving jobs" is a false dilemma. They are intertwined challenges and need to be addressed and solved together. ${ }^{86}$

\section{FROM UTOPIA TO SURVIVAL PLAN}

Westphalia left a mark. Although we live in a reality that is considerably different from that of classical International Law, part of its ideological infrastructure persist influencing and guiding norm creation and international relations. ${ }^{87}$ Some national leaders remain firm in the conviction that, in foreign affairs, one should consider only the direct interests of their States. At times, transnational cooperation occurs under the yoke of State sovereignty and to the extent that it suits the economic or ideological interests of each party ${ }^{88}$ However, we cannot consider that the posture of some populist leaders who temporarily occupy the leadership of their States is, unequivocally, the nation's posture itself. It is not for us to reduce Brazil to Jair Bolsonaro, or the US to Donald Trump.

In the Brazilian case, the acting President does not unanimously represent the position of his entire nation. In addition to the support of the federal government being visibly deteriorating, ${ }^{89}$ measures contrary to social isolation did not find repercussions in the federated entities: Brazilian governors and mayors positioned themselves directly against Bolsonaro's policies. The federal conflict resulted in a lawsuit before the Brazilian

${ }^{86}$ GEORGIEVA, Kristalina; GHEBREYESUS, Tedros Adhanom. Opening Remarks for Joint IMF/WHO press conference, IMF, Available at: <https://www.imf.org/en/News/Articles/2020/04/03/sp040320-opening-remarks-for-joint-imfwho-press-conference>, Accessed on 4 apr. 2020.

${ }^{87}$ MENEZES, A ONU e o Direito Internacional Contemporâneo, p. 327.

${ }^{88}$ In that respect, cf. ABADE, Denise Neves. Direitos Fundamentais na Cooperação Jurídica Internacional. E-Book. São Paulo: Saraiva, 2013.

${ }^{89}$ According to the survey, $50 \%$ of those interviewed considered the Government "Bad or Horrible," 25\% "Good or Great," 23\% "Regular" and 2\% could not answer. BACK, Richard et al. Pesquisa XP/IPESPE Maio 2020. São Paulo: XP/IPESPE, 2020.

MENEZES, Wagner; MARCOS, Henrique. International Law Post-Pandemic. In: Gonzalo Levi Obregón Salinas (Org.). Lo Multidisciplinario del Antes y Después del Covid-19. Ciudad de México: Thomson Reuters, 2020. (ISBN 978-607-474-571-9). Available at SSRN: https://ssrn.com/abstract=3680205 
Supreme Court ("Supremo Tribunal Federal"). The court was called to solve the dispute over the limits of the powers of the Brazilian Federal Union in the face of the common constitutional competence of the Brazilian federal states and municipalities before the health crisis. The majority of the judges of the Brazilian constitutional court decided that the federal government's actions could not empty the competence of the other federal entities. Thus, the court allowed member states and municipalities to rule against the federal government, authorizing them to implement social isolation, quarantine, and closure of businesses at local and regional levels. ${ }^{90}$

Looking at the State through a prism that reflects it as a multifaceted character, it is possible to collect national perspectives distinct from those represented by the Chief Executive's position. In this sense, the role of judges is to be highlighted. By realizing that their foreign colleagues are dealing with problems similar to their own, judges can structure (formally and informally) transnational networks of dialogue and judicial cooperation. ${ }^{91}$ In the global community of courts, judges have the opportunity to work collectively, aware of their collective efforts in defense of public interests that are ever so relevant than any disputes played out by some "supreme leader."

Similarly, in the present pandemic, the relevant role of business and the civil society is noticeable. ${ }^{92}$ In addition to the bio-pharmaceutical mentioned above ("Section 2") who denied the proposal of selling the exclusivity of the rights to COVID-19's cure, the also alluded "3M" adopted an interesting posture before the orders to cease the export of respirators to Markets other than the United States. The manufacturer pointed out the "humanitarian implications" of an eventual stance of this nature and, recognizing the responsibility of its role as an essential supplier of respirators, committed itself to

\footnotetext{
${ }^{90}$ Cf. "Supremo Tribunal Federal (Brazil). Plenário. ADI (MC-Ref) 6.341/DF, Rel. Min. Marco Aurélio, DJe 16/04/2020".

${ }^{91}$ SLAUGHTER, Anne-Marie. The Real New World Order. Foreign Affairs. v. 76, n. 5, p. 183-197, 1997. p. 187.

${ }^{92}$ In this regard, cf. MENEZES, Wagner. Cooperação Jurídica Internacional e seus Paradoxos, in: RAMOS, André de Carvalho; MENEZES, Wagner (Orgs.). Direito Internacional Privado e
} a Nova Cooperação Jurídica Internacional. Belo Horizonte: Arraes Editores, 2015.

MENEZES, Wagner; MARCOS, Henrique. International Law Post-Pandemic. In: Gonzalo Levi Obregón Salinas (Org.). Lo Multidisciplinario del Antes y Después del Covid-19. Ciudad de México: Thomson Reuters, 2020. (ISBN 978-607-474-571-9). Available at SSRN: https://ssrn.com/abstract=3680205 
maximize production and to persist exporting without any increase in price. ${ }^{93}$ In the face of the US positioning to cut funding to the WHO, the "Bill \& Melinda Gates Foundation" has increased $\$ 150$ million in additional funding to the international organization. ${ }^{94}$

Such postures cannot be naively interpreted as an ode to globalized capitalism. (A considerable part of the transnational business community has taken advantage of the crisis to maximize their earnings ${ }^{95}$ or take advantage of billionaire subsidies granted by local governments. $)^{96}$ Regardless, these conducts may represent a reflection — albeit purely pragmatic - in the face of the challenge instigated by COVID-19 and the possible consequences that failure to deal with the pandemic may cause. Perhaps this is why the proposed exclusivity of rights over a possible vaccine causes such astonishment. Similarly, ignoring patriotic bravado for electoral purposes, it is not easy to rationally justify why the US required " $3 \mathrm{M}$ " not to export respirators to the rest of the world. If the order were met and Canada (among other States) was prevented from providing respirators to those affected by COVID-19 in its territory, what would be the intensity of the impact (direct and indirect) that its neighbor to the South would face along the world's longest land border?

With its global reach, the pandemic serves as yet another item in the collection of unequivocal evidence that we live in one world, and, more often than not, we need to act in an internationally coordinated manner. However, the unique feature of the new

\footnotetext{
${ }_{93}$ 3M, 3M Response to Defense Production Act Order.

${ }^{94}$ KELLAND, Kate. Gates ups pandemic funds to $\$ \mathbf{2 5 0}$ million, says Trump WHO move makes "no sense", Reuters World News, Available at: < https://www.reuters.com/article/ushealth-coronavirus-gates-idUSKCN21X3FK>, Accessed on 17 jun. 2020.

${ }^{95}$ HOLDEN, Emily; STRAUSS, Daniel. The mystery of which US businesses are profiting from the coronavirus bailout, The Guardian, Available at: $<$ https://www.theguardian.com/us-news/2020/jun/09/us-congress-billions-coronavirus-aidrelief-package $>$, Accessed on 17 jun. 2020.

${ }^{96}$ NEWSOME, Scott. Coronavirus bailouts will cost taxpayers hundreds of billions of dollars - unlike past corporate rescues that actually made money for the US Treasury, The Conversation, Available at: <http://theconversation.com/coronavirus-bailoutswill-cost-taxpayers-hundreds-of-billions-of-dollars-unlike-past-corporate-rescues-that-actuallymade-money-for-the-us-treasury-136138>, Accessed on 17 jun. 2020.
}

MENEZES, Wagner; MARCOS, Henrique. International Law Post-Pandemic. In: Gonzalo Levi Obregón Salinas (Org.). Lo Multidisciplinario del Antes y Después del Covid-19. Ciudad de México: Thomson Reuters, 2020. (ISBN 978-607-474-571-9). Available at SSRN: https://ssrn.com/abstract=3680205 
coronavirus is that unlike other crises that were as serious as it but only had focal effects, COVID-19 also impacted rich nations. We are not facing an ecological crisis that affects just one island nation or a devastating viral outbreak in Africa. The coronavirus has claimed thousands of lives in Europe and the United States. Is that what it takes to finally think seriously about overcoming the primacy of State sovereignty in international relations?

The division of the world's peoples into sovereign nations is not an axiomatic fact of life on earth; it is a historical-political construction that still has legal effects. In turn, the biosphere is a tangible reality to which all earthlings are subject. International society designs and is designed by the Law. It depends on the Law as a regulatory tool, while the Law needs to adapt to society in a growing global interconnection scenario. The international environment is already cosmopolitan in its culture and economy and has always been so in an ecological reading. The peoples already act on this international stage; to continue doing so, they need a peaceful and cooperative international community. ${ }^{97}$ To follow the opposite path, i.e., the progression of the national shattering into self-contained kingdoms is to stagger on the precipice.

While these pages are being written, the COVID-19 pandemic is still ongoing. A vaccine or even natural immunization may resolve the crisis. However, different global cataclysms are possible. We live in a world interconnected not only by the flows of contemporary globalization but by being all subject to the consequences of the same ecological organization. In the face of possible crises that may come, world unity is not a cosmopolitan utopia. Human survival depends significantly on our ability to organize and act as a global community. Unfortunately, looking at the world's reaction to COVID19 , it does not seem that we are doing everything we should..$^{98}$

${ }^{97}$ MENEZES, Ordem Global e Transnormatividade, p. 30.

98 "What I am trying to show with these illustrations is that a century of experience and data has taught us these afflictions appear in spite of all the advances of medicine, and cannot be anticipated. The question that haunts my mind is, how would the United States handle such a pandemic outbreak if it occurred as the coronavirus did in China, just as some kind of major

MENEZES, Wagner; MARCOS, Henrique. International Law Post-Pandemic. In: Gonzalo Levi Obregón Salinas (Org.). Lo Multidisciplinario del Antes y Después del Covid-19. Ciudad de México: Thomson Reuters, 2020. (ISBN 978-607-474-571-9). Available at SSRN: https://ssrn.com/abstract=3680205 


\section{A SYSTEMIC APPROACH TO INTERNATIONAL LAW}

Contemporary International Law is an autonomous legal order organized in a logical system with its characteristics and elements through which States, international organizations, transnational entities, and even individuals establish and are subject to the rules that regulate international society. Within such a legal order, these actors are the agents that shape the international legal society that is established based on the very foundation of International Law that conceives it as an instrument at the service of human society ${ }^{99}$ In its function as an instrument, International Law serves to discipline the legal relationships established worldwide. Over the years, it has portrayed the evolution of humanity, including its periods of rapprochement and retraction. ${ }^{100}$

A considerable novelty of contemporary International Law is the phenomenon of the expansion and diversification of its normative geometry, extending its institutional scope and its regulatory purpose. As a result of the lack of a visible centralization in the international legal system, the phenomenon is interpreted by some as the fragmentation of International Law. ${ }^{101-102}$ The opposite interpretation of the fragmentary perspective proposes the reading of International Law as a system. The systemic view of International

climate change crisis was also stressing the American healthcare system. Are we prepared? I don't think so, do you? The reality is that not only America but the world is utterly unprepared for these outbreaks, and when one adds the migrations that cli- mate change will compel things look very bleak indeed." SCHWARTZ, Stephan A. Climate change, Covid-19, preparedness, and consciousness. Explore. v. 16, n. 3, p. 141-144, 2020.

${ }^{99}$ MENEZES, Wagner. International Law in Brazil. Boletim da Sociedade Brasileira de Direito Internacional: Edição Comemorativa Centenária. v. 103, n. 125-130, p. 12371311, 2017.

${ }^{100}$ MENEZES, Ordem Global e Transnormatividade, p. 30.

101 INTERNATIONAL LAW COMMISSION; KOSKENNIEMI, Martti. Fragmentation of International Law: Difficulties Arising from the Diversification and Expansion of International Law. Report of the Study Group of the International Law Commission - Finalized by Martti Koskenniemi (A/CN.4/L.682), 58th Session, Geneva, 1 May - 9 June and 3 July - 11 August 2006. 2006.

${ }^{102}$ KOSKENNIEMI, Martti; LEINO, Päivi. Fragmentation of International Law? Postmodern Anxieties. Leiden Journal of International Law. v. 15, n. 3, p. 553-580, 2002.

MENEZES, Wagner; MARCOS, Henrique. International Law Post-Pandemic. In: Gonzalo Levi Obregón Salinas (Org.). Lo Multidisciplinario del Antes y Después del Covid-19. Ciudad de México: Thomson Reuters, 2020. (ISBN 978-607-474-571-9). Available at SSRN: https://ssrn.com/abstract=3680205 
Law seeks to contribute to its evolution as a legal system by rationally conjugating its continuity (maintenance of its essence) with its change (evolution as a phenomenon). ${ }^{103}$

Incorporating the challenges inherent to such interpretative activity, the systemic effort seeks to organize the rules into a legal system that remains logically coherent despite the difficulties inherent to International Law: The lack of a hierarchical normative model and the absence of a central legislator. Thus, the systemic vision seeks to contribute to the conception and development of International Law so that it serves as a tool at the disposal of its subjects and, like a map before jurists in search of applicable norms, enables them to fill gaps, interpret norms, resolve conflicts between rules and, in essence, further solidify International Law as a legal order. In this way, the systemic view carries within itself an implicit authorization that enables jurists to take a step beyond the government's intention. It provides additional mechanisms for deepening the Law, provided that its interpreters maintain consistent and coherent legal arguments in the light of treaties and the development of customary International Law. ${ }^{104}$

In the debate about which of the two perspectives (systemic or fragmentary) should prevail, a plausible parameter to assist the decision is to consider which interpretation best achieves the underlying objective of International Law as an instrument at the service of human society. In other words, which of the interpretations best serves the purpose of justifying the Law as a normative tool? ${ }^{105}$ If this parameter is adopted from an internal point of view ${ }^{106}$ it seems that - despite the convincing arguments made by supporters of fragmentation - the perspective that tries to rescue the instrumentality of International Law should prevail. Moreover, it serves to emphasize

${ }^{103}$ BENVENISTI, Eyal. The Conception of International Law as a Legal System. German Yearbook of International Law. v. 50, p. 393-405, 2008.

${ }^{104}$ Ibid.

${ }^{105}$ DWORKIN, Ronald. A New Philosophy for International Law. Philosophy \& Public Affairs. v. 41, n. 1, p. 2-30, 2013. p. 22. DWORKIN, Ronald. Law's Empire. Cambridge: Belknap Press of Harvard University Press, 1986.

${ }^{106}$ SHAPIRO, Scott. What Is the Internal Point of View? Fordham Law Review. v. 75 , n. 3, p. $1157-1170,2006$.

MENEZES, Wagner; MARCOS, Henrique. International Law Post-Pandemic. In: Gonzalo Levi Obregón Salinas (Org.). Lo Multidisciplinario del Antes y Después del Covid-19. Ciudad de México: Thomson Reuters, 2020. (ISBN 978-607-474-571-9). Available at SSRN: https://ssrn.com/abstract=3680205 
the relevance of recognizing that interpretation is not an activity based on metaphysical efforts that seek to capture the true meaning of Law from a distinct ontological plane, but a propositional activity that builds its object from the best available arguments. ${ }^{107}$

This effort is close to the arguments in favor of the "principle of effectiveness" that states that international courts should guide their actions to ensure the international legal system's normative effectiveness. Thus, through its various modalities and internal techniques, interpretation should always aim at ensuring a reading of International Law that allows it to achieve its objectives. ${ }^{108}$ An explanatory hypothesis of the application of this rule was made in the "Turtle Shrimp Case" of the WTO. ${ }^{109}$ In the dispute, the Dispute Settlement Body (WTO-DSB) has moved away from an originalist position that sees the proper interpretation as one that reflects the parties' intention when negotiating agreements in favor of a deeper interpretation, reflecting contemporary environmental concerns in its decision. ${ }^{110}$

However, one should not confuse such an interpretative exercise with an immature idealism that ignores the defects of contemporary International Law. The current legal order has its flaws; its reform is a relevant claim that must be maintained. ${ }^{111}$ The current model that grants the United Nations Security Council (UNSC) an almost absolute monopoly on the use of force to maintain international peace and security, for

${ }^{107}$ HAGE, Jaap. Legal Reasoning and the Construction of Law. i-Lex - Scienze Giuridiche, Scienze Cognitive e Intelligenza Artificiale. n. 16, p. 81-105, 2012.

${ }^{108}$ BENVENISTI, The Conception of International Law as a Legal System.

${ }^{109}$ WTO, World Trade Organization. India etc. versus US: 'shrimp-turtle.' Case Nos. 58 (and 61) (United States - Import prohibition of certain shrimp and shrimp products. DS58/R DS58/AB/R DS58/AB/RW DS58/RW). 1998.

${ }^{110}$ STEINBERG, Richard H. Judicial Lawmaking at the WTO: Discursive, Constitutional, and Political Constraints. The American Journal of International Law. v. 98, n. 2, p. 247-275, 2004.

${ }^{111}$ MENEZES, Wagner. Reforma da Organização das Nações Unidas: Perspectivas \& Proposições a Partir do Direito Internacional, in: IV Conferência Nacional de Política Externa e Política Internacional (Rio de Janeiro, 2009). Brasília: FUNAG, 2010, p. 211-268.

MENEZES, Wagner; MARCOS, Henrique. International Law Post-Pandemic. In: Gonzalo Levi Obregón Salinas (Org.). Lo Multidisciplinario del Antes y Después del Covid-19. Ciudad de México: Thomson Reuters, 2020. (ISBN 978-607-474-571-9). Available at SSRN: https://ssrn.com/abstract=3680205 
example, should be subject to criticism and possible reformulation through appropriate channels. ${ }^{112}$

On the other hand, the operators of International Law must reflect and responsibly use the normative instruments at their disposal. The UNSC may be called upon to use its legal powers in the face of the present pandemic based on a thorough interpretation of Chapter VII of the Charter of the United Nations that portrays the COVID-19 crisis as a situation that poses a risk to world peace and security. ${ }^{113}$ Such a measure would be at risk of the use of veto power by one of the permanent members of the UNSC, especially China and the US, which, as seen above ("Section 2"), are protagonists in one of the most sensitive contemporary geopolitical disputes. In this sense, the internal national instances must act to pressure the international action of their national leaders, helping to overcome outdated conceptions of sovereignty in light of the contemporary responsibilities of States before International Law.

In this sense, we recall the analysis above ("Section 1") regarding WHO regulations. The organization has unique responsibilities and reasonable decision-making rules based on technical-scientific aspects that are especially relevant to deal with a pandemic crisis such as the one experienced today. As an international organization, however, the WHO also assumes the role of a joint forum for dialogue. In this way, the organization stands out as an international collective with clear objectives, but whose efficiency depends on the unambiguous cooperation of its Member States acting together for its higher purpose.

\footnotetext{
${ }^{112}$ MARCOS, Henrique Jerônimo Bezerra; GUERRA, Gustavo Rabay. Foxes in the Henhouse: Legal Critique to the "Jus Bellum Justum" Doctrine for Humanitarian Intervention through the Responsibility to Protect. Revista Jurídica Unicuritiba. v. 2, n. 59, p. 47, 2020. ${ }^{113}$ In a similar sense, cf. BERSCHINSKI, Rob. UN Security Council Can and Should Create a Global Goods Coordination Mechanism for Coronavirus, Just Security, Available at: $<$ https://www.justsecurity.org/69336/what-the-un-security-council-can-do-on-coronavirus-aglobal-goods-coordination-mechanism/>, Accessed on 3 apr. 2020.

MENEZES, Wagner; MARCOS, Henrique. International Law Post-Pandemic. In: Gonzalo Levi Obregón Salinas (Org.). Lo Multidisciplinario del Antes y Después del Covid-19. Ciudad de México: Thomson Reuters, 2020. (ISBN 978-607-474-571-9). Available at SSRN: https://ssrn.com/abstract=3680205
} 


\section{FINAL REMARKS}

In its lasting waltz, international relations are determined by two movements: Integrating cooperation and isolationist nationalism. The future is uncertain. Postpandemic International Law operators may witness a revolution as a new international society based on principles of universal ethics and common scientific development. On the other hand, it is entirely plausible that States keep moving further and further away from a common cosmopolitan objective.

Nevertheless, if Westphalia lives, the "paradigm" is getting closer to a paradoxical reverie revealing an ideology fated to legal and economic failure. Even so, its spirit keeps influencing contemporary geopolitics. The Nation-State has not lost its regalia. Perhaps it will never cease to be one of the most important pieces of international chess. Nonetheless, to ignore the relevance of cooperative movements is to deliver the destiny of humanity to the fate of not being able to properly deal with a future crisis that could be even more serious than COVID-19.

It is naïve to ignore the practical difficulty of implementing sufficient cooperative measures to address these global issues effectively. However, the complexity of the challenge before us cannot serve as an absolute condemnation. It is not only up to the operators of the Law to call for the reform of the existing institutions so that they are adapted to global needs, but it is also their responsibility to use and interpret the instruments that are currently available in the best possible way in order to achieve the most venerable purpose of International Law: The peaceful progress of humanity.

\section{REFERENCES}

3M. 3M Response to Defense Production Act Order. 3M News, United States. Available at: $<$ https://news.3m.com/press-release/company-english/3m-response-defense-production-act-order $>$. Accessed on 4 apr. 2020.

ABADE, Denise Neves. Direitos Fundamentais na Cooperação Jurídica Internacional. E-Book. São Paulo: Saraiva, 2013.

MENEZES, Wagner; MARCOS, Henrique. International Law Post-Pandemic. In: Gonzalo Levi Obregón Salinas (Org.). Lo Multidisciplinario del Antes y Después del Covid-19. Ciudad de México: Thomson Reuters, 2020. (ISBN 978-607-474-571-9). Available at SSRN: https://ssrn.com/abstract=3680205 
ABEDI, Maham. Coronavirus: Trump asks medical supply firm 3M to stop selling N95 respirators to Canada. Global News. Available at: <https://globalnews.ca/news/6772979/coronavirus3m-n95-respirators-trump-canada/>. Accessed on 3 apr. 2020.

ANDERSEN, Kristian G.; RAMBAUT, Andrew; LIPKIN, W. Ian; et al. The Proximal Origin of SARSCoV-2. Nature Medicine, v. 26, n. 4, p. 450-452, 2020.

ARAUJO, Ernesto. Chegou o Comunavírus. Metapolítica 17. Available at: <https://www.metapoliticabrasil.com/post/chegou-o-comunavírus>. Access on: 15 jun. 2020.

BACK, Richard; SANTOS, Debora; GAMA, Paulo; et al. Pesquisa XP/IPESPE May 2020. São Paulo: XP/IPESPE, 2020. Available at: <https://conteudos.xpi.com.br/politica/pesquisa-xp-maio-2020-tendenciade-aumento-na-reprovacao-ao-presidente-jair-bolsonaro/>.

BBC. Trump accuses WHO of being a "puppet of China". BBC News. Available at: <https://www.bbc.com/news/health-52679329>. Accessed on 10 jun. 2020.

BEAUMONT, Peter. Where did Covid-19 come from? What we know about its origins. The Guardian, 2020. Available at: <https://www.theguardian.com/world/2020/may/01/could-covid-19-be-manmade-whatwe-know-about-origins-trump-chinese-lab-coronavirus >. Accessed on 9 jun. 2020.

BENVENISTI, Eyal. The Conception of International Law as a Legal System. German Yearbook of International Law, v. 50, p. 393-405, 2008.

BERSCHINSKI, Rob. UN Security Council Can and Should Create a Global Goods Coordination Mechanism for Coronavirus. Just Security. Available at: <https://www.justsecurity.org/69336/whatthe-un-security-council-can-do-on-coronavirus-a-global-goods-coordination-mechanism/ $>$. Accessed on 3 apr. 2020.

BLOFIELD, Merike; HOFFMANN, Bert; LLANOS, Mariana. Assessing the Political and Social Impact of the COVID-19 Crisis in Latin America. GIGA Focus, Latin America, v. 3, 2020.

BOBBIO, Norberto. A Era dos Direitos. 7. ed. Rio de Janeiro: Elsevier, 2004.

BUTLER, Judith. Capitalism Has its Limits. Verse. Available at: <https://www.versobooks.com/blogs/4603-capitalism-has-its-limits>. Access on: 17 jun. 2020.

CASSIDY, Julie. Emergence of the Individual as an International Juristic Entity: Enforcement of International Human Rights. Deakin Law Review, v. 9, n. 2, p. 533-572, 2004.

CONFORTI, Benedetto. Diritto Internazionale. $6^{\mathrm{a}}$ ed. Napoli: Editoriale Scientifica, 2002.

DEUTSCHE WELLE. US accused of seizing face mask shipments bound for Europe, Canada | DW | 03.04.2020. DW.COM. Available at: <https://www.dw.com/en/us-accused-of-seizing-face-maskshipments-bound-for-europe-canada/a-53010923>. Accessed on 10 jun. 2020.

DEUTSCHE WELLE. US firm denies German "piracy" claims over vanished face masks | DW | 04.04.2020. DW.COM. Available at: <https://www.dw.com/en/us-firm-denies-german-piracy-claims-overvanished-face-masks/a-53017112>. Accessed on 10 jun. 2020.

MENEZES, Wagner; MARCOS, Henrique. International Law Post-Pandemic. In: Gonzalo Levi Obregón Salinas (Org.). Lo Multidisciplinario del Antes y Después del Covid-19. Ciudad de México: Thomson Reuters, 2020. (ISBN 978-607-474-571-9). Available at SSRN: https://ssrn.com/abstract=3680205 
DOD, Department of Defense of the United States of America. First DOD Defense Production Act

Title 3 COVID-19 Project. U.S. Department of Defense. Available at: <https://www.defense.gov/Newsroom/Releases/Release/Article/2146692/first-dod-defense-production-acttitle-3-covid-19-project/>. Accessed on 10 jun. 2020.

DUGYALA, Rishika. Trump places travel restrictions on Brazil. POLITICO. Available at: <https://www.politico.com/news/2020/05/24/trump-travel-restrictions-brazil-277633>. Accessed on 15 jun. 2020.

DUPUY, Pierre-Marie. L'Unité de L'Ordre Juridique International. Cours Général de Droit International Public, v. 297, n. 9, pp. 9-490, 2002. (Recueil des Cours. The Hague Academy of International Law).

DRNAS DE CLÉMENT, Z. The Humanisation of International Courts In: VUKAS, Budislav; ŠOŠIĆ, Trpimir (Org.). International Law: New Actors, New Concepts, Continuing Dilemmas: Liber amicorum Božidar Bakotić. Leiden: Brill, 2010.

DWORKIN, Ronald. A New Philosophy for International Law. Philosophy \& Public Affairs, v. 41, n. 1, p. $2-30,2013$.

DWORKIN, Ronald. Law's Empire. Cambridge: Belknap Press of Harvard University Press, 1986.

FBI, Federal Bureau of Investigation; CISA, Cybersecurity and Infrastructure Security Agency. People's Republic of China (PRC) Targeting of COVID-19 Research Organizations. Public Service Announcement (Unclassified). 2020. Available at: <https://www.cisa.gov/sites/default/files/publications/Joint_FBICISA_PSA_PRC_Targeting_of_COVID-19_Research_Organizations_S508C.pdf $>$. Accessed on 9 jun. 2020.

FRIEDMANN, Wolfgang. Change of Structure in International Law. Rio de Janeiro: Freitas Bastos Bookstore, 1971.

GEORGIEVA, Kristalina; GHEBREYESUS, Tedros Adhanom. Opening Remarks for Joint IMF/WHO press conference. Available at: <https://www.imf.org/en/News/Articles/2020/04/03/sp040320-opening-remarks-for-joint-imf-who-pressconference $>$. Accessed on 4 apr. 2020.

GROSS, Leo. The Peace of Westphalia, 1648-1948. The American Journal of International Law, v. 42, n. 1 , p. $20-41,1948$.

HAGE, Jaap. Legal Reasoning and the Construction of Law. i-Lex - Scienze Giuridiche, Scienze Cognitive e Intelligenza Artificiale, n. 16, p. 81-105, 2012.

HINDUSTAN TIMES. 'The only way forward for WHO is...': Full text of Trump's letter to WHO chief. Hindustan Times. Available at: <https://www.hindustantimes.com/world-news/the-only-wayforward-for-the-who-is-full-text-of-trump-s-letter-to-who-chief-tedros-adhanom-ghebreyesus/storyMCee8MiYg9NYh7gPcYMGRO.html>. Accessed on 10 jun. 2020.

HOLDEN, Emily; STRAUSS, Daniel. The mystery of which US businesses are profiting from the coronavirus bailout. The Guardian. Available at: < https://www.theguardian.com/usnews/2020/jun/09/us-congress-billions-coronavirus-aid-relief-package>. Accessed on 17 jun. 2020.

MENEZES, Wagner; MARCOS, Henrique. International Law Post-Pandemic. In: Gonzalo Levi Obregón Salinas (Org.). Lo Multidisciplinario del Antes y Después del Covid-19. Ciudad de México: Thomson Reuters, 2020. (ISBN 978-607-474-571-9). Available at SSRN: https://ssrn.com/abstract=3680205 
INTERNATIONAL LAW COMMISSION; KOSKENNIEMI, Martti. Fragmentation of International Law: Difficulties Arising from the Diversification and Expansion of International Law. Report of the Study Group of the International Law Commission - Finalized by Martti Koskenniemi (A/CN.4/L.682), 58th Session, Geneva, 1 May - 9 June and 3 July - 11 August 2006. 2006. Available at: <https://legal.un.org/ilc/documentation/english/a_cn4_1682.pdf>. Accessed on 3 apr. 2020.

JAPAN TIMES. Like Trump, Brazil's Jair Bolsonaro also bets big on chloroquine. The Japan Times. Available at: <https://www.japantimes.co.jp/news/2020/05/21/world/brazil-jair-bolsonarohydroxychloroquine/>. Accessed on 11 jun. 2020.

KARAGIANNIS, Syméon. La Multiplication des Juridictions Internationales: Un Système Anarchique? In: SOCIETE FRANÇAISE POUR LE DROIT INTERNATIONAL (Org.). Colloque de Lille: La Juridictionnalisation du Droit International. Paris: A. Pedone, 2003.

KELLAND, Kate. Gates ups pandemic funds to $\$ 250$ million, says Trump WHO move makes "no sense". Reuters World News. Available at: <https://www.reuters.com/article/us-health-coronavirusgates-idUSKCN21X3FK>. Accessed on 17 jun. 2020.

KELSEN, Hans. Principles of International Law. New York: Rinehart \& Company, 1952.

KINGSBURY, Benedict. What, How, and Who Should Public International Law Regulate? New Problems of Global Administrative Governance. (Lecture Series). Available at:

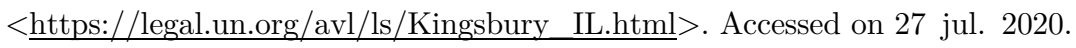

KOSKENNIEMI, Martti; LEINO, Päivi. Fragmentation of International Law? Postmodern Anxieties. Leiden Journal of International Law, v. 15, n. 3, p. 553-580, 2002.

MARCOS, Henrique Jerônimo Bezerra. A Apreciação Judicial dos Atos do Conselho de Segurança pela Corte Internacional de Justiça em uma Perspectiva Kelseniana. Dissertação de Mestrado (Ciências Jurídicas), Universidade Federal da Paraíba (UFPB), Centro de Ciências Jurídicas (CCJ), João Pessoa, 2018.

MARCOS, Henrique Jerônimo Bezerra. O Patriotismo Constitucional enquanto Instrumento de Cooperação e Integração Jurídica Internacional. In: MENEZES, Wagner (Org.). Direito Internacional em Expansão - Volume XVII. Belo Horizonte: Arraes Editores, 2019.

MARCOS, Henrique Jerônimo Bezerra; GUERRA, Gustavo Rabay. Foxes in the Henhouse: Legal Critique to the "Jus Bellum Justum" Doctrine for Humanitarian Intervention through the Responsibility to Protect. Revista Jurídica Unicuritiba, v. 2, n. 59, p. 47, 2020.

MENEZES, Wagner. A ONU e o Direito Internacional Contemporâneo. In: CACHAPUZ DE MEDEIROS, Antônio Paulo (Org.). Desafios do Direito Internacional Contemporâneo (Jornadas de Direito Internacional Público no Itamaraty, 7 a 9 de novembro de 2005). Brasília: FUNAG, 2007, p. 460.

MENEZES, Wagner. Cooperação Jurídica Internacional e seus Paradoxos. In: RAMOS, André de Carvalho; MENEZES, Wagner (Orgs.). Direito Internacional Privado e a Nova Cooperação Jurídica Internacional. Belo Horizonte: Arraes Editores, 2015.

MENEZES, Wagner. International Law in Brazil. Boletim da Sociedade Brasileira de Direito Internacional: Edição Comemorativa Centenária, v. 103, n. 125-130, p. 1237-1311, 2017.

MENEZES, Wagner; MARCOS, Henrique. International Law Post-Pandemic. In: Gonzalo Levi Obregón Salinas (Org.). Lo Multidisciplinario del Antes y Después del Covid-19. Ciudad de México: Thomson Reuters, 2020. (ISBN 978-607-474-571-9). Available at SSRN: https://ssrn.com/abstract=3680205 
Available at SSRN: https://ssrn.com/abstract $=3680205$

MENEZES, Wagner. Ordem Global e Transnormatividade. Ijuí: Editora Unijuí, 2005.

MENEZES, Wagner. Reforma da Organização das Nações Unidas: Perspectivas \& Proposições a Partir do Direito Internacional. In: IV Conferência Nacional de Política Externa e Política Internacional (Rio de Janeiro, 2009). Brasília: FUNAG, 2010, p. 211-268.

MENEZES, Wagner. Tribunais Internacionais: Jurisdição e Competência. São Paulo: Saraiva, 2013.

NEWSOME, Scott. Coronavirus bailouts will cost taxpayers hundreds of billions of dollars unlike past corporate rescues that actually made money for the US Treasury. The Conversation. Available at: <http://theconversation.com/coronavirus-bailouts-will-cost-taxpayers-hundreds-of-billions-ofdollars-unlike-past-corporate-rescues-that-actually-made-money-for-the-us-treasury-136138>. Accessed on 17 jun. 2020.

NSOESIE, Elaine Okanyene; RADER, Benjamin; BARNOON, YiyaoL; et al. Analysis of Hospital Traffic and Search Engine Data in Wuhan China indicates Early Disease activity in the Fall of 2019. Cambridge: Harvard Medical School, 2020. Available at: <https://dash.harvard.edu/handle/1/42669767>. Accessed on 9 jun. 2020.

OLTERMANN, Philip. Coronavirus: anger in Germany at report Trump seeking exclusive vaccine deal. The Guardian. Available at: <https://www.theguardian.com/world/2020/mar/16/not-forsale-anger-in-germany-at-report-trump-seeking-exclusive-coronavirus-vaccine-deal $>$. Accessed on 10 jun. 2020.

ORAN, Daniel P.; TOPOL, Eric J. Prevalence of Asymptomatic SARS-CoV-2 Infection. Annals of Internal Medicine, 2020. Available at: <https://www.acpjournals.org/doi/10.7326/M20-3012>. Accessed on 9 jun. 2020 .

PARAGUASSU, Lisandra. U.S. denies hijacking Chinese medical supplies meant for Brazil. Reuters. Available at: <https://www.reuters.com/article/us-health-coronavirus-brazil-usaidUSKBN21P315>. Accessed on 15 jun. 2020.

REUTERS. Bolsonaro calls WHO "political," threatens Brazil exit. Reuters World News. Available at: <https://www.reuters.com/article/us-health-coronavirus-brazil-bolsonaro-idUSKBN23C353>. Accessed on 10 jun. 2020 .

SARAIVA, Augusta. Trump: Brazil having "a very hard time" with coronavirus. The Brazilian Report. Available at: <https://brazilian.report/coronavirus-brazil-live-blog/2020/06/05/trump-brazilhaving-a-very-hard-time-with-coronavirus/>. Accessed on 15 jun. 2020.

SCHWARTZ, Stephan A. Climate change, Covid-19, preparedness, and consciousness. Explore, v. 16, n. 3, p. $141-144,2020$.

SCIENCE MEDIA CENTER. Expert Reaction to Letter sent from Donald Trump to Dr Tedros Adhanom, Director-General of the WHO. SMC, Science Media Center. Available at: $<$ https://www.sciencemediacentre.org/expert-reaction-to-letter-sent-from-donald-trump-to-dr-tedrosadhanom-director-general-of-the-who/>. Accessed on 10 jun. 2020.

SHAPIRO, Scott. What Is the Internal Point of View? Fordham Law Review, v. 75, n. 3, p. 1157-1170, 2006 .

MENEZES, Wagner; MARCOS, Henrique. International Law Post-Pandemic. In: Gonzalo Levi Obregón Salinas (Org.). Lo Multidisciplinario del Antes y Después del Covid-19. Ciudad de México: Thomson Reuters, 2020. (ISBN 978-607-474-571-9). Available at SSRN: https://ssrn.com/abstract=3680205 
Available at SSRN: https://ssrn.com/abstract $=3680205$

SHAW, Malcolm N. International Law. 8. ed. New York: Cambridge University Press, 2017.

SINGER, Peter. One World: The Ethics of Globalization. New Haven: Yale University Press, 2002.

SLAUGHTER, Anne-Marie. The Real New World Order. Foreign Affairs, v. 76, n. 5, p. 183-197, 1997.

SOMERVILLE, Ewan. Donald Trump accuses China of "mass worldwide killing" over virus. Evening Standard. Available at: <https://www.standard.co.uk/news/world/donald-trump-chinacoronavirus-a4446286.html>. Accessed on 10 jun. 2020.

STEINBERG, Richard H. Judicial Lawmaking at the WTO: Discursive, Constitutional, and Political Constraints. The American Journal of International Law, v. 98, n. 2, p. 247-275, 2004.

TRINDADE, Antônio Augusto Cançado. International Law for Humankind: Towards a New Jus Gentium. Leiden: Martinus Nijhoff Publishers, 2010.

TRUMP, Donald J. Donald J. Trump (@realDonaldTrump) on Twitter: "This is the letter sent to Dr. Tedros of the World Health Organization. It is self-explanatory! https://t.co/pF2kzPUpDv" / 11:55 PM, May 18, 2020, Twitter for iPhone. Twitter. Available at: <https://twitter.com/realDonaldTrump/status/1262577580718395393>. Accessed on 10 jun. 2020.

TZENG, Peter. Taking China to the International Court of Justice over COVID-19. European Journal of International Law, EJIL: Talk!, 2020. Available at: <https://www.ejiltalk.org/taking-china-to-theinternational-court-of-justice-over-covid-19/>. Accessed on 2 apr. 2020.

VIGNALI, Heber Arbuet. Derecho Internacional Publico: temas de la teoría general. Montevidéo: Talleres grafico, 1993.

VON BOGDANDY, Armin; VILLARREAL, Pedro. Critical Features of International Authority in Pandemic Response: The WHO in the COVID-19 Crisis, Human Rights and the Changing World Order. Rochester, NY: Social Science Research Network, 2020. Available at: $<$ https://papers.ssrn.com/abstract=3600058 $>$. Accessed on 6 jun. 2020a.

VON BOGDANDY, Armin; VILLARREAL, Pedro. International Law on Pandemic Response: A First Stocktaking in Light of the Coronavirus Crisis. Rochester, NY: Social Science Research Network, 2020. Available at: <https://papers.ssrn.com/abstract=3561650>. Accessed on 6 jun. 2020b.

WALTERMAnN, Antonia. Reconstructing Sovereignty. Cham: Springer, 2019. Available at: <https://doi.org/10.1007/978-3-030-30004-3>. Accessed on 19 jun. 2020.

WEISSERT, Will. DHS report: China hid virus' severity to hoard supplies. AP NEWS. Available at: <https://apnews.com/bf685dcf52125be54e030834ab7062a8>. Accessed on 9 jun. 2020.

WHO, World Health Organization. IHR Emergency Committee on Novel Coronavirus (2019nCoV). World Health Organization. Available at: <https://www.who.int/dg/speeches/detail/who-directorgeneral-s-statement-on-ihr-emergency-committee-on-novel-coronavirus-(2019-ncov) $>$. Accessed on 9 jun. 2020.

MENEZES, Wagner; MARCOS, Henrique. International Law Post-Pandemic. In: Gonzalo Levi Obregón Salinas (Org.). Lo Multidisciplinario del Antes y Después del Covid-19. Ciudad de México: Thomson Reuters, 2020. (ISBN 978-607-474-571-9). Available at SSRN: https://ssrn.com/abstract=3680205 
WHO, World Health Organization. Munich Security Conference, World Health Organization, 15 February 2020. Available at: <https://www.who.int/dg/speeches/detail/munich-security-conference>, accessed on: 9 jun. 2020 .

WHO, World Health Organization. Pneumonia of Unknown Cause - China. World Health Organization. Available at: <http://www.who.int/csr/don/05-january-2020-pneumonia-of-unkown-causechina/en/>. Accessed on 9 jun. 2020.

WHO, World Health Organization. WHO Coronavirus Disease (COVID-19) Dashboard. World Health Organization. Available at: <https://covid19.who.int/>. Accessed on 15 jun. 2020.

WTO, World Trade Organization. India etc. versus US: 'shrimp-turtle'. Case Nos. 58 (and 61) (United States - Import prohibition of certain shrimp and shrimp products. DS58/R DS58/AB/R DS58/AB/RW DS58/RW). 1998. Available at: <https://www.wto.org/english/tratop_e/envir_e/edis08_e.htm>. Accessed on 19 jun. 2020.

ZASTROW, Mark. South Korea is reporting intimate details of COVID-19 cases: has it helped? Nature, 2020. Available at: <https://www.nature.com/articles/d41586-020-00740-y>. Accessed on 8 jun. 2020.

MENEZES, Wagner; MARCOS, Henrique. International Law Post-Pandemic. In: Gonzalo Levi Obregón Salinas (Org.). Lo Multidisciplinario del Antes y Después del Covid-19. Ciudad de México: Thomson Reuters, 2020. (ISBN 978-607-474-571-9). Available at SSRN: https://ssrn.com/abstract=3680205 